\title{
Cellulomonas chitinilytica sp. nov., a chitinolytic bacterium isolated from cattle-farm compost
}

Correspondence

Wan-Taek Im

wandra@kaist.ac.kr
Min-Ho Yoon, ${ }^{1}$ Leonid N. Ten, ${ }^{2}$ Wan-Taek $\mathrm{Im}^{3}$ and Sung-Taik Lee ${ }^{3}$

${ }^{1}$ Department of BioEnvironmental Chemistry, College of Agriculture and Life Sciences, Chungnam National University, Daejeon 305-764, Republic of Korea

${ }^{2}$ Department of Biology and Medicinal Science, Pai Chai University, 14 Yeonja-1-Gil, Seo-Gu, Daejeon 302-735, Republic of Korea

${ }^{3}$ Department of Biological Sciences, Korea Advanced Institute of Science and Technology, 373-1, Guseong-dong, Yuseong-gu, Daejeon 305-701, Republic of Korea
A bacterial strain, designated X.bu- $\mathrm{b}^{\top}$, with chitin-, xylan-, cellulose- and starch-degrading activities, was isolated from compost at a cattle farm near Daejeon, Republic of Korea. The strain comprised Gram-positive, aerobic or facultatively anaerobic, non-motile, rod-shaped bacteria. On the basis of an analysis of 16S rRNA gene sequences, the phylogenetic position of X.bu- $\mathrm{b}^{\top}$ was within the genus Cellulomonas, and the strain exhibited relatively high sequence similarities with respect to Cellulomonas biazotea DSM $20112^{\top}$ (98.1\%), C. cellasea DSM $20118^{\top}$ (98.1\%), C. fimi DSM $20113^{\top}$ (98.0\%), C. terrae DB5 ${ }^{\top}$ (97.9\%), C. humilata ATCC $25174^{\top}$ (97.7\%), C. xylanilytica XIL11 ${ }^{\top}(97.5 \%)$, C. uda DSM $20107^{\top}(97.4 \%)$, C. gelida DSM $20111^{\top}$ $(97.3 \%)$, C. iranensis $\mathrm{O}^{\top}(97.3 \%)$ and C. flavigena DSM $20109^{\top}(97.0 \%)$. The phylogenetic distance from other Cellulomonas species with validly published names was greater than $3 \%$ (i.e. less than $97.0 \%$ sequence similarity). Chemotaxonomic data also supported the classification of strain X.bu-b ${ }^{\top}$ within the genus Cellulomonas: L-ornithine was the cell-wall diamino acid, anteiso- $\mathrm{C}_{15: 0}$ and anteiso- $\mathrm{C}_{17: 0}$ were the major fatty acids, rhamnose, galactose, xylose and ribose were the cell-wall sugars, $\mathrm{MK}-\mathrm{g}\left(\mathrm{H}_{4}\right)$ was the predominant menaquinone and diphosphatidylglycerol and phosphatidylglycerol were present in the polar lipids. The $G+C$ content of the genomic DNA was $73.6 \mathrm{~mol} \%$. DNA-DNA hybridization experiments showed that the values for DNA-DNA relatedness between strain $X . b u-b^{\top}$ and the phylogenetically closest neighbours were below $23 \%$. On the basis of its phenotypic properties and phylogenetic distinctiveness, strain X.bu-b ${ }^{\top}$ represents a novel species of the genus Cellulomonas, for which the name Cellulomonas chitinilytica sp. nov. is proposed. The type strain is X.bu- $\mathrm{b}^{\top}$ (=KCTC $19133^{\top}=$ DSM $17922^{\top}$ ).
Polysaccharide-degrading enzymes such as cellulase, chitinase and xylanase are widespread in nature. They can be found in every type of organism, including mammals, plants, algae, moulds, bacteria and phages (Terra \& Ferreira, 1994; Bhat, 2000; Oshima et al., 2002). For the production of polysaccharases, micro-organisms are usually the most convenient sources and can be obtained from various natural environments.

The GenBank/EMBL/DDBJ accession number for the 16S rRNA gene sequence of strain X.bu-b ${ }^{\top}$ is $A B 268586$.

Results of 2D TLC showing the polar lipids of strain $X . b u-b^{\top}$ and tables listing selected characteristics and fatty acids of $X . b u-b^{\top}$ in comparison with those of related Cellulomonas species are available as supplementary material with the online version of this paper.
During the course of a study on the polysaccharidedegrading bacterial community, using a developed agar plate screening technique (Ten et al., 2004), a large number of bacteria were isolated from compost at a cattle farm near Daejeon (Republic of Korea). Among those isolates was strain X.bu-b ${ }^{\mathrm{T}}$, which was able to break down chitin, cellulose, xylan and starch. On the basis of $16 \mathrm{~S}$ rRNA gene sequence data, the strain was found to be a member of the genus Cellulomonas, which currently contains 14 species with validly published names (Bagnara et al., 1985; Stackebrandt \& Keddie, 1986; Funke et al., 1995; Collins \& Pascual, 2000; Elberson et al., 2000; Rivas et al., 2004; An et al., 2005; Brown et al., 2005; Jones et al., 2005; Yi et al., 2007). Further study of this strain, based on a polyphasic approach that included chemotaxonomic, physiological and DNA-DNA hybridization analyses, confirmed its 
position as a representative of novel species within the genus Cellulomonas.

Strain X.bu-b ${ }^{\mathrm{T}}$ was isolated from compost by using nutrient agar plates supplemented with insoluble coloured substrates, as described previously (Ten et al., 2004). After isolation, strain X.bu- ${ }^{T}$ was cultivated by being transferred onto R2A agar (Difco) every month. Stock cultures were preserved as suspensions in glycerol $(20 \%, \mathrm{v} / \mathrm{v})$ at $-70{ }^{\circ} \mathrm{C}$. Biomass for chemotaxonomic studies was prepared by growing the strain in shake flasks containing R2A broth (Difco) at 150 r.p.m. for 3 days at $25^{\circ} \mathrm{C}$. Cultures were checked for purity, harvested by centrifugation and freeze-dried.

The Gram reaction was determined using the non-staining method, as described by Buck (1982). Cell morphology was observed under a Nikon light microscope at $\times 1000$, with cells grown for 3 days at $25{ }^{\circ} \mathrm{C}$ on R2A agar. Catalase and oxidase tests were performed as outlined by Cappuccino \& Sherman (2002). For single-carbon-source assimilation studies, a defined liquid medium was used made up of a basal salt medium containing the following $\left(\mathrm{g} \mathrm{l}^{-1}\right): 1.8 \mathrm{~g}$ $\mathrm{K}_{2} \mathrm{HPO}_{4}, 1.08 \mathrm{~g} \mathrm{KH}_{2} \mathrm{PO}_{4}, 0.5 \mathrm{~g} \mathrm{NaNO}_{3}, 0.5 \mathrm{~g} \mathrm{NH}_{4} \mathrm{Cl}, 0.1 \mathrm{~g}$ $\mathrm{KCl}, 0.1 \mathrm{~g} \mathrm{MgSO}_{4}$ and $0.05 \mathrm{~g} \mathrm{CaCl}_{2}$. A vitamin solution (Widdel \& Bak, 1992), trace element solution SL-10 (Widdel et al., 1983) and selenite/tungstate solution (Tschech \& Pfennig, 1984) were added to this medium, and the $\mathrm{pH}$ was adjusted to 6.8 . Aliquots $(0.25 \mathrm{ml})$ of this liquid medium were added to the wells of a 96-well tray and then filter-sterilized carbon sources were added $(0.1 \%$, $\mathrm{w} / \mathrm{v}$, in each case). Growth was examined visually, after incubation at $25{ }^{\circ} \mathrm{C}$ for 7 days. The negative-control well did not contain an added carbon source. The positive control well contained R2A broth. Some physiological characteristics were determined with API 20E, API 20NE and API 32GN galleries according to the instructions of the manufacturer (bioMérieux). Tests for anaerobic growth was performed in serum bottles containing R2A broth supplemented with thioglycolate $\left(1 \mathrm{~g} \mathrm{l}^{-1}\right)$ under a nitrogen atmosphere. Nitrate- and nitrite-reduction tests were performed in serum bottles containing R2A broth supplemented with $\mathrm{KNO}_{3} \quad(10 \mathrm{mM})$ and $\mathrm{NaNO}_{2}$ $(10 \mathrm{mM})$, respectively. The reduction of nitrate and nitrite was monitored by using an ion chromatograph (model 790 personal IC; Metrohm) equipped with a conductivity detector and an anion-exchange column (Metrosep Anion Supp 4; Metrohm). Tests for the degradation of DNA [DNase activity; using DNase agar (Scharlau) and flooding plates with $1 \mathrm{M} \mathrm{HCl}$, casein, starch (Atlas, 1993), lipid (Kouker \& Jaeger, 1987), chitin, xylan, cellulose and collagen (Ten et al., 2004, 2005) were performed and evaluated after 7 days. Growth at different temperatures $(0$,

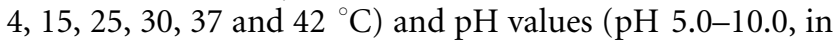
increments of $0.5 \mathrm{pH}$ units) was assessed after incubation for up to 5 days. The effect of $\mathrm{pH}$ on growth was determined on R2A broth medium by using three different buffers (final concentration, $50 \mathrm{mM}$ ): acetate buffer (for $\mathrm{pH}$ 5.0-5.5), phosphate buffer (for $\mathrm{pH}$ 6.0-8.0) and Tris buffer (for $\mathrm{pH}$ 8.5-10.0). Salt tolerance was tested on R2A medium supplemented with $\mathrm{NaCl}$ at $1-10 \%(\mathrm{w} / \mathrm{v})$ after incubation for up 5 days. Growth on nutrient agar, trypticase soy agar (TSA; Difco) and MacConkey agar was also evaluated at $25{ }^{\circ} \mathrm{C}$.

For the phylogenetic analysis of strain X.bu- ${ }^{\mathrm{T}}$, DNA was extracted using a genomic DNA extraction kit (Core Biosystem), the 16S rRNA gene was amplified by using a PCR and then sequencing of the purified PCR product was carried out, as described by Kim et al. (2005). The complete 16S rRNA gene sequence was compiled using SeqMan software (DNASTAR). The 16S rRNA gene sequences of related taxa were obtained from the GenBank database. Multiple alignments were performed by using the CLUSTAL_X program (Thompson et al., 1997). Gaps were edited in the BioEdit program (Hall, 1999). Evolutionary distances were calculated using Kimura's two-parameter model (Kimura, 1983). Phylogenetic trees were constructed by using the neighbour-joining (Saitou \& Nei, 1987) and maximum-parsimony (Fitch, 1971) methods in the MEGA3 program (Kumar et al., 2004), with bootstrap values based on 1000 replications (Felsenstein, 1985).

Purified cell walls were obtained according to the modified method of Schleifer \& Kandler (1972), as follows: $2 \mathrm{~g}$ wet cell material was suspended in $0.05 \mathrm{M}$ phosphate buffer ( $\mathrm{pH}$ 7.2) and sonicated three times for $10 \mathrm{~min}$ in iced water. After centrifugation at $4000 \mathrm{~g}$ for $20 \mathrm{~min}$, the supernatant was transferred to a new tube, which was then centrifuged at $40000 \mathrm{~g}$ for $25 \mathrm{~min}$. After precipitated debris had been obtained, a $4 \%$ SDS solution $(6 \mathrm{ml})$ was added and the resuspended material was transferred to a glass tube and maintained at $100{ }^{\circ} \mathrm{C}$ for $40 \mathrm{~min}$ until it became colourless. It was then centrifuged at $40000 \mathrm{~g}$ for $25 \mathrm{~min}$ at room temperature and washed three times with water. Hydrolysis of the purified cell walls was carried out by using $6 \mathrm{M} \mathrm{HCl}$ at $100{ }^{\circ} \mathrm{C}$ for $16 \mathrm{~h}$. Amino acids and peptides in the cell-wall hydrolysates were analysed by using two-dimensional TLC on cellulose plates with the solvent systems described by Schleifer \& Kandler (1972). Cell-wall sugars were analysed as described by Staneck \& Roberts (1974). Menaquinones were extracted from cells grown on R2A broth and then analysed as described by Komagata \& Suzuki (1987), using reversed-phase HPLC. Cellular fatty acids were analysed from bacteria grown on TSA for 2 days at $25{ }^{\circ} \mathrm{C}$. The cellular fatty acids were saponified, methylated, extracted and identified by using the Microbial Identification software package (Sasser, 1990). Polar lipids were extracted and examined by using two-dimensional TLC (Minnikin et al., 1984).

The $\mathrm{G}+\mathrm{C}$ content of the chromosomal DNA was determined, as described by Mesbah et al. (1989), using reversedphase HPLC. DNA-DNA hybridization was performed fluorometrically by using the method of Ezaki et al. (1989), with photobiotin-labelled DNA probes (Sigma) and microdilution wells (Greiner). Five hybridization replications were 
performed for each sample: the highest and lowest values obtained for each sample were excluded and the means of the remaining three values are quoted as DNA hybridization values.

Cells of strain X.bu- $\mathrm{b}^{\mathrm{T}}$ were found to be Gram-positive, non-motile, straight rods, $0.4-0.6 \mu \mathrm{m}$ in diameter and 1.5$2.2 \mu \mathrm{m}$ long. Colonies on R2A agar were circular, convex, entire, smooth and yellowish within 3 days at $25{ }^{\circ} \mathrm{C}$. The strain showed a positive result for catalase activity but was negative for oxidase activity, it was aerobic or facultatively anaerobic, it could reduce nitrate to nitrite and it could hydrolyse chitin, xylan, CM-cellulose and starch. The strain grew at $4-30{ }^{\circ} \mathrm{C}$ but not at 0 or $37^{\circ} \mathrm{C}$; the optimum temperature was $25^{\circ} \mathrm{C}$. Growth was observed at $\mathrm{pH}$ 5.08.5, the optimum $\mathrm{pH}$ being 7.0-7.5. Strain X.bu- $\mathrm{b}^{\mathrm{T}}$ has a phenotypic profile that distinguishes it from representatives of all species of the genus Cellulomonas with validly published names (Table 1). Moreover, strain X.bu-b ${ }^{\mathrm{T}}$ could be easily differentiated from its phylogenetically closest relatives, Cellulomonas biazotea and Cellulomonas fimi, using tests for the utilization of substrates as sole carbon sources (see Supplementary Table S1, available in IJSEM Online). In particular, in contrast to both of the abovementioned species, strain X.bu- ${ }^{\mathrm{T}}$ was able to assimilate Dmannitol, gluconate, phenyl acetate and malonate but did not utilize L-rhamnose or lactate.

The peptidoglycan composition of strain X.bu- $\mathrm{b}^{\mathrm{T}}$ corresponded to type A4 $\beta$ : it contained L-ornithine-D-glutamic acid, which is the composition reported for most members of the genus Cellulomonas and has been emphasized as an important feature for delineation at the genus level within the Actinobacteria (Stackebrandt \& Schumann, 2000). The cell-wall sugars of strain X.bu-b ${ }^{\mathrm{T}}$ were rhamnose, galactose, xylose and ribose. The cellular fatty acid profiles of strain X.bu- $\mathrm{b}^{\mathrm{T}}$ and its closest neighbours are shown in Supplementary Table S2. The major fatty acids of strain X.bu- $\mathrm{b}^{\mathrm{T}}$ were anteiso- $\mathrm{C}_{15: 0}(61.3 \%)$ and anteiso- $\mathrm{C}_{17: 0}$ $(15.9 \%)$. The fatty acid profile was similar to those of Cellulomonas species analysed previously, although there were differences in the proportions of some fatty acids, perhaps because of differences in cultivation conditions (Funke et al., 1995; An et al., 2005). The polar lipids detected were diphosphatidylglycerol, phosphatidylglycerol, an unidentified lipid, two unidentified phospholipids and three unidentified phosphoglycolipids (Supplementary Fig. S1). The predominant isoprenoid quinone in strain X.bu- $\mathrm{b}^{\mathrm{T}}$ was a tetrahydrogenated menaquinone with nine isoprene units [MK-9 $\left.\left(\mathrm{H}_{4}\right)\right]$, which is the major lipoquinone found in members of the family Cellulomonadaceae.

Comparative 16S rRNA gene sequence analysis for strain X.bu- ${ }^{T}$ (1460 bp) showed that it is phylogenetically affiliated to species of the genus Cellulomonas. In the phylogenetic tree based on the neighbour-joining algorithm (Fig. 1), strain X.bu-b ${ }^{T}$ occupies a distinct phylogenetic position within the genus Cellulomonas. The almost-complete 16S rRNA gene sequence of strain
X.bu- $\mathrm{b}^{\mathrm{T}}$ exhibited relatively high levels of similarity with respect to C. biazotea DSM $20112^{\mathrm{T}}(98.1 \%)$, Cellulomonas cellasea DSM $20118^{\mathrm{T}}$ (98.1\%), C. fimi DSM 20113 (98.0\%), Cellulomonas terrae DB5 $^{\mathrm{T}}$ (97.9\%), Cellulomonas humilata ATCC $25174^{\mathrm{T}}$ (97.7\%), Cellulomonas xylanilytica XIL11 ${ }^{\mathrm{T}}(97.5 \%)$, Cellulomonas uda DSM $20107^{\mathrm{T}}(97.4 \%)$, Cellulomonas gelida DSM $20111^{\mathrm{T}}(97.3 \%)$, Cellulomonas iranensis $\mathrm{O}^{\mathrm{T}}(97.3 \%)$, Cellulomonas flavigena DSM $20109^{\mathrm{T}}$ (97.0\%), Cellulomonas persica $\mathrm{I}^{\mathrm{T}}(96.8 \%)$ and Cellulomonas denverensis ATCC BAA- $788^{\mathrm{T}}(96.7 \%)$. The phylogenetic distances, based on 16S rRNA gene sequence similarity, from any other species within the family Cellulomonadaceae with validly published names, including Cellulomonas hominis ATCC $51964^{\mathrm{T}}$ and Cellulomonas bogoriensis DSM $16987^{\mathrm{T}}$, were above $3.7 \%$. The generally recommended and accepted criteria for delineating bacterial species state that strains with a DNA-DNA relatedness below $70 \%$ (as measured from hybridization) or with a $16 \mathrm{~S}$ rRNA gene sequence dissimilarity above $3 \%$ are considered to belong to separate species (Wayne et al., 1987; Stackebrandt \& Goebel, 1994; Stackebrandt et al., 2002). In view of this definition, the above-mentioned data indicate that strain X.bu- $\mathrm{b}^{\mathrm{T}}$ can be considered to represent a novel species of the genus Cellulomonas. For further verification of the taxonomic position of strain X.bu- $\mathrm{b}^{\mathrm{T}}$, DNA-DNA hybridization was performed with the members of the genus Cellulomonas most closely related to it. Strain X.bu-b ${ }^{\mathrm{T}}$ exhibited relatively low levels of DNA-DNA relatedness values with respect to C. fimi KCTC $9143^{\mathrm{T}}(23 \%)$, C. biazotea KCTC $1370^{\mathrm{T}}$ (18\%), C. terrae KCTC $19081^{\mathrm{T}}(12 \%)$, C. cellasea KCTC $3410^{\mathrm{T}}(15 \%)$, C. humilata JCM $11945^{\mathrm{T}}(11 \%)$, C. uda KCTC $1441^{\mathrm{T}}(10 \%)$, C. xylanilytica LMG $21723^{\mathrm{T}}(10 \%)$, C. iranensis KCTC $9983^{\mathrm{T}}(8 \%)$, C. gelida KCTC $3231^{\mathrm{T}}(8 \%)$, C. persica KCTC $9984^{\mathrm{T}}(10 \%)$, C. flavigena KCTC $9104^{\mathrm{T}}$ $(7 \%)$ and C. denverensis DSM $15764^{\mathrm{T}}(7 \%)$, indicating that it is not related to them at the species level (Wayne et al., 1987). The DNA G $+C$ content of the strain was found to be $73.6 \mathrm{~mol} \%$, a value that falls within the range reported for members of the genus Cellulomonas.

The results obtained from the phenotypic and phylogenetic characterizations indicated that strain X.bu- $\mathrm{b}^{\mathrm{T}}$ belongs to the genus Cellulomonas. The phylogenetic distinctiveness, DNA-DNA hybridization results and the presence of some differential phenotypic features (Table 1 and Supplementary Table S1) serve to confirm that strain X.bu- $\mathrm{b}^{\mathrm{T}}$ represents a species that is distinct from recognized Cellulomonas species. Therefore, on the basis of the data presented, strain X.bu-b ${ }^{\mathrm{T}}$ should be classified within the genus Cellulomonas as a novel species, for which the name Cellulomonas chitinilytica sp. nov. is proposed.

\section{Description of Cellulomonas chitinilytica sp. nov.}

Cellulomonas chitinilytica (chi.ti.ni.ly'ti.ca. N.L. n. chitinum chitin; Gr. adj. lutikos able to loosen, able to dissolve; N.L. adj. lytica dissolving; N.L. fem. adj. chitinilytica decomposing chitin). 
Table 1. Comparison of selected characteristics of strain $\mathrm{X} \cdot \mathrm{bu}-\mathrm{b}^{\top}$ with those of its nearest phylogenetic neighbours in the genus Cellulomonas

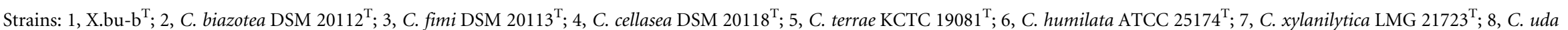

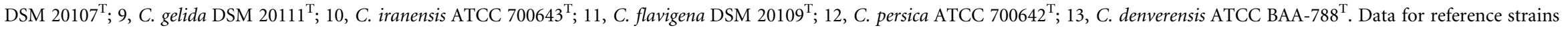

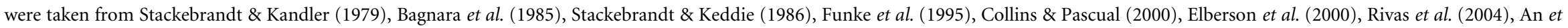

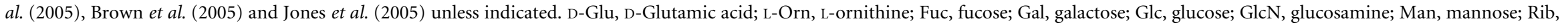
ribose; Rha, rhamnose; 6dTal, 6-deoxytalose; Xyl, xylose; ai, anteiso-branched; i, iso-branched. +, Positive; -, negative; w, weakly positive; ND, no data available.

\begin{tabular}{|c|c|c|c|c|c|c|c|c|c|c|c|c|c|}
\hline Characteristic & 1 & 2 & 3 & 4 & 5 & 6 & 7 & 8 & 9 & 10 & 11 & 12 & 13 \\
\hline Motility & - & + & + & - & - & - & - & - & + & + & - & + & + \\
\hline Morphology & Rods & Rods & Rods & Rods & Rods & $\begin{array}{c}\text { Rods, coccoid, } \\
\text { diphtheroid }\end{array}$ & $\begin{array}{l}\text { Rods, } \\
\text { coccoid }\end{array}$ & Rods & Rods & Rods & Rods & Rods & Rods \\
\hline Mycelium & - & - & - & - & $\mathrm{ND}$ & + & - & - & - & - & - & - & - \\
\hline Colony colour & Yellow & $\begin{array}{l}\text { Yellow- } \\
\text { white }\end{array}$ & Yellow-white & Yellow & Yellow & White & Yellow & White & $\begin{array}{c}\text { Yellow- } \\
\text { white }\end{array}$ & $\begin{array}{l}\text { Yellow- } \\
\text { white }\end{array}$ & Yellow & $\begin{array}{l}\text { Yellow- } \\
\text { white }\end{array}$ & Pale yellow \\
\hline $\begin{array}{l}\text { Nitrate } \\
\text { reduction }\end{array}$ & + & + & $-^{*}$ & + & + & - & + & + & + & + & + & + & + \\
\hline Peptidoglycan & $\begin{array}{l}\text { L-Orn-D- } \\
\text { Glu }\end{array}$ & $\begin{array}{l}\text { L-Orn-D- } \\
\text { Glu }\end{array}$ & L-Orn-D-Glu & L-Orn-D-Glu & L-Orn-D-Glu & L-Orn-D-Glu & $\begin{array}{l}\text { L-Orn-D- } \\
\text { Glu }\end{array}$ & $\begin{array}{l}\text { L-Orn-D- } \\
\text { Glu }\end{array}$ & $\begin{array}{l}\text { L-Orn-D- } \\
\text { Glu }\end{array}$ & $\begin{array}{l}\text { L-Orn-D- } \\
\text { Asp }\end{array}$ & $\begin{array}{l}\text { L-Orn-D- } \\
\text { Asp }\end{array}$ & $\begin{array}{l}\text { L-Orn-D- } \\
\text { Asp }\end{array}$ & ND \\
\hline Cell-wall sugars & $\begin{array}{l}\text { Gal, Rib, } \\
\text { Xyl, Rha }\end{array}$ & $\begin{array}{l}\text { GlcN, Rha, } \\
\text { 6dTal, Gal }\end{array}$ & $\begin{array}{l}\text { GlcN, Rha, } \\
\text { Fuc }\end{array}$ & $\begin{array}{l}\text { Rha, Man, } \\
\text { 6dTal }\end{array}$ & Rha, Gal, Glc & Rha, Glc, Fuc & $\begin{array}{l}\text { Man, Rha, } \\
\text { Fuc }\end{array}$ & GlcN, Glc & GlcN, Glc & $\begin{array}{l}\text { GlcN, Rha, } \\
\text { Glc, Man }\end{array}$ & $\begin{array}{l}\text { GlcN, Rha, } \\
\text { Rib, Man }\end{array}$ & $\begin{array}{l}\text { GlcN, Rha, } \\
\text { Glc, Man }\end{array}$ & $\begin{array}{l}\text { Man, Rha, } \\
\text { Rib }\end{array}$ \\
\hline \multicolumn{14}{|l|}{ Utilization of: } \\
\hline Acetate & + & + & $+^{*}$ & - & - & - & - & + & + & + & + & + & ND \\
\hline Gluconate & + & - & - & - & - & + & - & - & - & - & + & - & ND \\
\hline D-Lactose & + & + & + & - & + & + & + & + & + & - & + & - & $\mathrm{ND}$ \\
\hline Lactate & - & + & + & + & - & - & - & - & - & - & - & - & $\mathrm{ND}$ \\
\hline D-Mannose & + & + & + & + & + & + & + & + & + & + & + & + & $\mathrm{ND}$ \\
\hline D-Mannitol & + & - & - & + & - & + & - & $\mathrm{ND}$ & $\mathrm{ND}$ & $\mathrm{ND}$ & ND & ND & $\mathrm{ND}$ \\
\hline Raffinose & + & + & - & - & ND & $\mathrm{ND}$ & ND & - & - & - & - & - & $\mathrm{ND}$ \\
\hline L-Rhamnose & - & + & + & - & $\mathrm{W}$ & + & + & - & - & + & - & $\mathrm{ND}$ & $\mathrm{ND}$ \\
\hline D-Ribose & - & - & $+^{*}$ & - & - & $\mathrm{ND}$ & - & - & - & - & + & - & $\mathrm{ND}$ \\
\hline \multicolumn{14}{|l|}{ Fermentation of: } \\
\hline D-Glucose & - & + & + & + & + & + & + & + & + & $\mathrm{ND}$ & + & $\mathrm{ND}$ & + \\
\hline L-Rhamnose & - & + & + & - & ND & + & + & - & - & $\mathrm{ND}$ & - & $\mathrm{ND}$ & + \\
\hline Sucrose & - & + & + & + & + & + & + & + & + & $\mathrm{ND}$ & + & $\mathrm{ND}$ & + \\
\hline D-Mannitol & - & - & - & + & ND & + & ND & - & - & $\mathrm{ND}$ & - & ND & - \\
\hline \multicolumn{14}{|l|}{ Enzyme activity } \\
\hline Catalase & + & + & + & + & - & - & + & + & + & $\mathrm{ND}$ & + & $\mathrm{ND}$ & + \\
\hline DNase & - & - & ND & - & + & $\mathrm{ND}$ & ND & + & + & + & - & + & ND \\
\hline Cellulase & $\mathrm{W}$ & + & + & + & + & $\mathrm{ND}$ & + & + & + & + & + & + & $\mathrm{ND}$ \\
\hline $\begin{array}{l}\text { Gelatin } \\
\text { hydrolysis }\end{array}$ & + & + & + & - & ND & $\mathrm{w}$ & $\mathrm{w}$ & + & + & $\mathrm{w}$ & + & $\mathrm{w}$ & - \\
\hline Urease & - & - & - & - & - & - & - & - & - & + & - & + & - \\
\hline
\end{tabular}




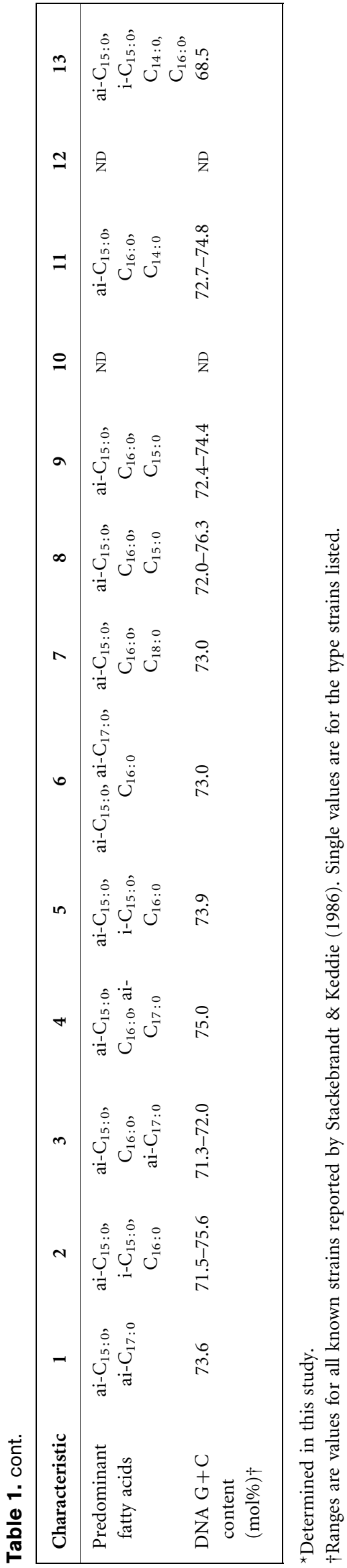

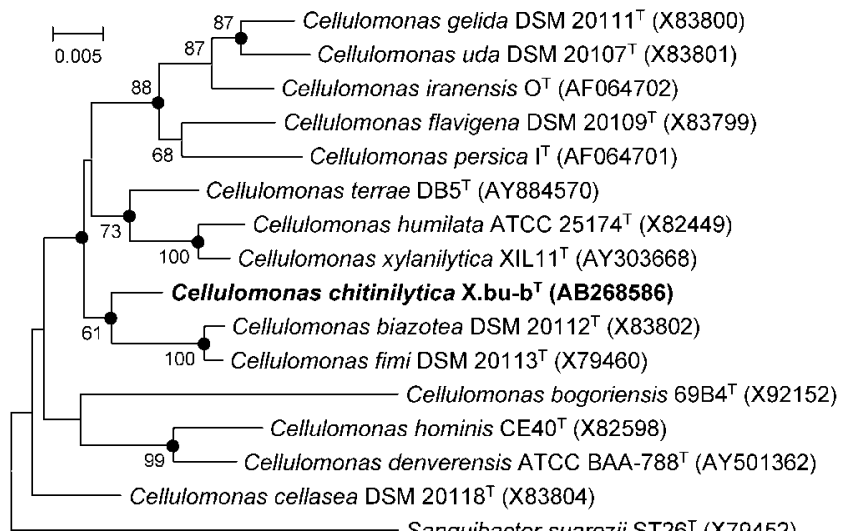

Sanguibacter suarezii ST26' (X79452)

Fig. 1. Neighbour-joining phylogenetic tree, based on $16 \mathrm{~S}$ rRNA gene sequences, showing the relationships between strain X.bu$\mathrm{b}^{\top}$ and members of the genus Cellulomonas. Bootstrap percentages (based on 1000 replications) greater than $50 \%$ are shown at branch points. Filled circles indicate that the corresponding nodes were also recovered in the tree generated with the maximum-parsimony algorithm (not shown). The tree was rooted by using Sanguibacter suarezii $\mathrm{ST}^{2} 6^{\top}$ as an outgroup. Bar, 0.005 substitutions per nucleotide position.

Cells are Gram-positive, aerobic or facultatively anaerobic, non-motile and rod-shaped. Colonies on R2A agar are circular, convex, entire, smooth and yellowish within 3 days at $25{ }^{\circ} \mathrm{C}$. Grows between 4 and $30{ }^{\circ} \mathrm{C}$, the optimum temperature being $25^{\circ} \mathrm{C}$. The $\mathrm{pH}$ range for growth is $\mathrm{pH}$ 5.0-8.5, with an optimum between $\mathrm{pH} 6.9$ and 7.5. $\mathrm{NaCl}$ is not required for growth; $2 \%(\mathrm{w} / \mathrm{v}) \mathrm{NaCl}$ is tolerated. Catalase-positive and oxidase-negative. Growth occurs on nutrient agar and TSA, but not on MacConkey agar. Nitrate is reduced to nitrite aerobically but not anaerobically. Hydrolyses chitin, xylan, CM-cellulose (weakly) and starch, but not casein, collagen or DNA. The following substrates are utilized for growth: Dgalactose, D-arabinose, L-arabinose, D-fructose, D-glucose, D-mannose, L-xylose, D-xylose, D-lyxose, maltose, trehalose, raffinose, D-lactose, melibiose, cellobiose, sucrose, gluconate, acetate, formate, phenyl acetate, malonate, pyruvate, dulcitol, methanol, glycerol, xylitol, D-sorbitol, D-mannitol, D-adonitol, amygdalin, glycogen, $\mathrm{N}$-acetyl-D-glucosamine, salicin, L-cysteine and L-glutamate. The following substrates are not utilized for growth: L-rhamnose, L-fucose, Dribose, L-sorbose, ethanol, inositol, dextran, inulin, citrate, lactate, DL-3-hydroxybutyrate, valerate, fumarate, malate, succinate, itaconate, propionate, caprate, glutarate, adipate, suberate, benzoate, maleate, oxalate, 3-hydroxybenzoate, 4hydroxybenzoate, tartrate, 2-ketogluconate, 5-ketogluconate, L-alanine, L-arginine, L-aspartate, L-asparagine, L-glutamine, glycine, L-isoleucine, L-histidine, L-lysine, Lproline, L-serine, L-threonine, L-leucine, L-methionine, Lvaline, L-phenylalanine, L-tryptophan and L-tyrosine. In API $20 \mathrm{E}$ tests, $\beta$-galactosidase and the Voges-Proskauer reaction give weakly positive results, gelatin hydrolysis give 
a positive result and arginine dihydrolase, lysine decarboxylase, ornithine decarboxylase, tryptophan deaminase, urease, hydrogen sulphide and indole production produce negative results. Acid is produced weakly from $\mathrm{L}$-arabinose, but acid is not produced from D-glucose, L-rhamnose, Dmannitol, inositol, D-sorbitol, amygdalin, sucrose or melibiose. The predominant isoprenoid quinone is MK$9\left(\mathrm{H}_{4}\right)$. Phosphatidylglycerol, diphosphatidylglycerol and unidentified phospholipids and phosphoglycolipids are the major polar lipids. The major fatty acids are anteiso- $\mathrm{C}_{15: 0}$ $(61.3 \%)$, anteiso- $\mathrm{C}_{17: 0}(15.9 \%)$ and iso- $\mathrm{C}_{17: 0}(5.4 \%)$. The $\mathrm{G}+\mathrm{C}$ content of the genomic DNA of the type strain is $73.6 \mathrm{~mol} \%$. The peptidoglycan contains L-Orn-D-Glu (type A4 $\beta$ ). The cell-wall sugars are galactose, ribose, xylose and rhamnose.

The type strain, X.bu-b ${ }^{\mathrm{T}}\left(=\right.$ KCTC $19133^{\mathrm{T}}=$ DSM $\left.17922^{\mathrm{T}}\right)$, was isolated from compost at a cattle farm near Daejeon, Republic of Korea.

\section{Acknowledgements}

We thank Jean Euzéby for his help with the etymology of the species epithet. This work was supported by the 21C Frontier Microbial Genomics and Application Center Program, Ministry of Science and Technology (grant MG05-0101-4-0), Republic of Korea.

\section{References}

An, D.-S., Im, W.-T., Yang, H.-C., Kang, M. S., Kim, K. K., Jin, L., Kim, M. K. \& Lee, S.-T. (2005). Cellulomonas terrae sp. nov., a cellulolytic and xylanolytic bacterium isolated from soil. Int J Syst Evol Microbiol 55, 1705-1709.

Atlas, R. M. (1993). Handbook of Microbiological Media. Edited by L. C. Parks. Boca Raton, FL: CRC Press.

Bagnara, C., Toci, R., Gaudin, C. \& Belaich, J. P. (1985). Isolation and characterization of a cellulolytic microorganism, Cellulomonas fermentans sp. nov. Int J Syst Bacteriol 35, 502-507.

Bhat, M. K. (2000). Cellulases and related enzymes in biotechnology. Biotechnol Adv 18, 355-383.

Brown, J. M., Frazier, R. P., Morey, R. E., Steigerwalt, A. G., Pellegrini, G. J., Daneshvar, M. I., Hollis, D. G. \& McNeil, M. M. (2005). Phenotypic and genetic characterization of clinical isolates of CDC coryneform group A-3: proposal of a new species of Cellulomonas, Cellulomonas denverensis sp. nov. J Clin Microbiol 43, 1732-1737.

Buck, J. D. (1982). Nonstaining (KOH) method for determination of Gram reactions of marine bacteria. Appl Environ Microbiol 44, 992-993.

Cappuccino, J. G. \& Sherman, N. (2002). Microbiology: a Laboratory Manual, 6th edn. Menlo Park, CA: Benjamin/Cummings.

Collins, M. D. \& Pascual, C. (2000). Reclassification of Actinomyces humiferus (Gledhill and Casida) as Cellulomonas humilata nom. corrig., comb. nov. Int J Syst Evol Microbiol 50, 661-663.

Elberson, M. A., Malekzadeh, F., Yazdi, M. T., Kameranpour, N., Noori-Daloii, M. R., Matte, M. H., Shahamat, M., Colwell, R. R. \& Sowers, K. R. (2000). Cellulomonas persica sp. nov. and Cellulomonas iranensis sp. nov., mesophilic cellulose-degrading bacteria isolated from forest soils. Int J Syst Evol Microbiol 50, 993-996.

Ezaki, T., Hashimoto, Y. \& Yabuuchi, E. (1989). Fluorometric deoxyribonucleic acid-deoxyribonucleic acid hybridization in microdilution wells as an alternative to membrane filter hybridization in which radioisotopes are used to determine genetic relatedness among bacterial strains. Int J Syst Bacteriol 39, 224-229.

Felsenstein, J. (1985). Confidence limits on phylogenies: an approach using the bootstrap. Evolution 39, 783-791.

Fitch, W. M. (1971). Toward defining the course of evolution: minimum change for a specific tree topology. Syst Zool 20, 406-416.

Funke, G., Ramos, C. P. \& Collins, M. D. (1995). Identification of some clinical strains of CDC coryneform group A-3 and A-4 bacteria as Cellulomonas species and proposal of Cellulomonas hominis sp. nov. for some group A-3 strains. J Clin Microbiol 33, 2091-2097.

Hall, T. A. (1999). BioEdit: a user-friendly biological sequence alignment editor and analysis program for Windows 95/98/NT. Nucleic Acids Symp Ser 41, 95-98.

Jones, B. E., Grant, W. D., Duckworth, A. W., Schumann, P., Weiss, N. \& Stackebrandt, E. (2005). Cellulomonas bogoriensis sp. nov., an alkaliphilic cellulomonad. Int J Syst Evol Microbiol 55, 1711-1714.

Kim, M. K., Im, W.-T., Ohta, H., Lee, M. \& Lee, S.-T. (2005). Sphingopyxis granuli sp. nov., a $\beta$-glucosidase producing bacterium in the family Sphingomonadaceae in $\alpha-4$ subclass of the Proteobacteria. J Microbiol 43, 152-157.

Kimura, M. (1983). The Neutral Theory of Molecular Evolution. Cambridge: Cambridge University Press.

Komagata, K. \& Suzuki, K. (1987). Lipid and cell-wall analysis in bacterial systematics. Methods Microbiol 19, 161-207.

Kouker, G. \& Jaeger, K. E. (1987). Specific and sensitive plate assay for bacterial lipases. Appl Environ Microbiol 53, 211-213.

Kumar, S., Tamura, K. \& Nei, M. (2004). MEGA3: integrated software for molecular evolutionary genetics analysis and sequence alignment. Brief Bioinform 5, 150-163.

Mesbah, M., Premachandran, U. \& Whitman, W. B. (1989). Precise measurement of the $\mathrm{G}+\mathrm{C}$ content of deoxyribonucleic acid by highperformance liquid chromatography. Int J Syst Bacteriol 39, 159-167.

Minnikin, D. E., O'Donnell, A. G., Goodfellow, M., Alderson, G., Athalye, M., Schaal, A. \& Parlett, J. H. (1984). An integrated procedure for the extraction of bacterial isoprenoid quinones and polar lipids. J Microbiol Methods 2, 233-241.

Oshima, H., Miyazaki, R., Ohe, Y., Hayashi, H., Kawamura, K. \& Kikuyama, S. (2002). Isolation and sequence of a novel amphibian pancreatic chitinase. Comp Biochem Physiol B Biochem Mol Biol 132, 381-388.

Rivas, R., Trujillo, M. E., Mateos, P. F., Martínez-Molina, E. \& Velázquez, E. (2004). Cellulomonas xylanilytica sp. nov., a cellulolytic and xylanolytic bacterium isolated from a decayed elm tree. Int J Syst Evol Microbiol 54, 533-536.

Saitou, N. \& Nei, M. (1987). The neighbor-joining method: a new method for reconstructing phylogenetic trees. Mol Biol Evol 4, 406-425.

Sasser, M. (1990). Identification of bacteria by gas chromatography of cellular fatty acids, MIDI Technical Note 101. Newark, DE: MIDI Inc.

Schleifer, K. H. \& Kandler, O. (1972). Peptidoglycan types of bacterial cell walls and their taxonomic implications. Bacteriol Rev 36, 407-477.

Stackebrandt, E. \& Goebel, B. M. (1994). Taxonomic note: a place for DNA-DNA reassociation and $16 \mathrm{~S}$ rRNA sequence analysis in the present species definition in bacteriology. Int J Syst Bacteriol 44, 846-849.

Stackebrandt, E. \& Kandler, O. (1979). Taxonomy of the genus Cellulomonas, based on phenotypic characters and deoxyribonucleic acid-deoxyribonucleic acid homology, and proposal of seven neotype strains. Int J Syst Bacteriol 29, 273-282. 
Stackebrandt, E. \& Keddie, R. M. (1986). Genus Cellulomonas. In Bergey's Manual of Systematic Bacteriology, vol. 2, pp. 1325-1329. Edited by P. H. A. Sneath, N. S. Mair, M. E. Sharpe \& J. G. Holt. Baltimore: Williams \& Wilkins.

Stackebrandt, E. \& Schumann, P. (2000). Description of Bogoriellaceae fam. nov., Dermacoccaceae fam. nov., Rarobacteraceae fam. nov. and Sanguibacteraceae fam. nov. and emendation of some families of the suborder Micrococcineae. Int J Syst Evol Microbiol 50, 1279-1285.

Stackebrandt, E., Frederiksen, W., Garrity, G. M., Grimont, P. A. D., Kämpfer, P., Maiden, M. C., Nesme, X., Rosselló-Mora, R., Swings, J. $\&$ other authors (2002). Report of the ad hoc committee for the reevaluation of the species definition in bacteriology. Int J Syst Evol Microbiol 52, 1043-1047.

Staneck, J. L. \& Roberts, G. D. (1974). Simplified approach to identification of aerobic actinomycetes by thin-layer chromatography. Appl Microbiol 28, 226-231.

Ten, L. N., Im, W.-T., Kim, M.-K., Kang, M.-S. \& Lee, S.-T. (2004). Development of a plate technique for screening of polysaccharidedegrading microorganisms by using a mixture of insoluble chromogenic substrates. J Microbiol Methods 56, 375-382.

Ten, L. N., Im, W.-T., Kim, M.-K. \& Lee, S.-T. (2005). A plate assay for simultaneous screening of polysaccharide- and protein-degrading microorganisms. Lett Appl Microbiol 40, 92-98.

Terra, W. R. \& Ferreira, C. (1994). Insect digestive enzymes: properties, compartmentalization and function. Comp Biochem Physiol B Biochem Mol Biol 109, 1-62.
Thompson, J. D., Gibson, T. J., Plewniak, F., Jeanmougin, F. \& Higgins, D. G. (1997). The CLUSTAL_X windows interface: flexible strategies for multiple sequence alignment aided by quality analysis tools. Nucleic Acids Res 25, 4876-4882.

Tschech, A. \& Pfennig, N. (1984). Growth yield increase linked to caffeate reduction in Acetobacterium woodii. Arch Microbiol 137, 163-167.

Wayne, L. G., Brenner, D. J., Colwell, R. R., Grimont, P. A. D., Kandler, O., Krichevsky, M. I., Moore, L. H., Moore, W. E. C., Murray, R. G. E. \& other authors (1987). International Committee on Systematic Bacteriology. Report of the ad hoc committee on reconciliation of approaches to bacterial systematics. Int J Syst Bacteriol 37, 463-464.

Widdel, F. \& Bak, F. (1992). Gram-negative mesophilic sulfatereducing bacteria. In The Prokaryotes, 2nd edn, pp. 3352-3378. Edited by A. Balows, H. G. Trüper, M. Dworkin, W. Harder \& K. H. Schleifer. New York: Springer.

Widdel, F., Kohring, G. \& Mayer, F. (1983). Studies on dissimilatory sulfate-reducing bacteria that decompose fatty acids. III. Characterization of the filamentous gliding Desulfonema limicola gen. nov. sp. nov., and Desulfonema magnum sp. nov. Arch Microbiol 134, 286-294.

Yi, H., Schumann, P. \& Chun, J. (2007). Demequina aestuarii gen. nov., sp. nov., a novel actinomycete of the suborder Micrococcineae, and reclassification of Cellulomonas fermentans Bagnara et al. 1985 as Actinotalea fermentans gen. nov., comb. nov. Int J Syst Evol Microbiol 57, 151-156. 